JOURNAL OF SECURITY AND SUSTAINABILITY ISSUES

ISSN 2029-7017 print/ISSN 2029-7025 online

2019 September Volume 9 Number 1

http://doi.org/10.9770/jssi.2019.9.1(2)

Scopus

\title{
ELIMINATION OF THE INFLUENCE OF INVESTMENT, FINANCIAL AND OPERATIONAL RISKS ON THE ORGANISATION ECONOMIC SECURITY
}

\author{
Mariia V. Dykha ${ }^{1}$, Larysa Liubokhynets ${ }^{2}$, Nataliia P. Tanasiienko ${ }^{3}$, Serhiy Moroz ${ }^{4}$, Olga Poplavska ${ }^{5}$ \\ $1^{*, 2,3,4,5}$ Khmelnytsky National University, 11, Instytutska Street, Khmelnytsky, 29016, Ukraine;
}

E-mail: ${ }^{1}$ koaduep@gmail.com

Received 25 November 2018; accepted 24 May 2019; published 30 September 2019

\begin{abstract}
This scientific paper considers the essence of investment, financial and operational activity of the enterprise in the context of provision of a high level of its economic security, and describes the importance of investment support for the economic activity of the enterprise and the place of investments for the factor of economic security. The method of estimation of investment, financial and operational risks based on matrix and expert approaches was offered. The modelling of the systemic risk impact on the economic security of the enterprise was performed and recommendations on the neutralization of the influence of risks were developed.
\end{abstract}

Keywords: systemic risks, economic security, security breach, investment process stages, matrix of risk analysis, expert evaluations

Reference to this paper should be made as follows: Dykha, M.V.; Liubokhynets, L.; Tanasiienko, N.P.; Moroz, S.; Poplavska, O. 2019. Elimination of the influence of investment, financial and operational risks on the organisation economic security, Journal of Security and Sustainability Issues 9(1): 13-26. http://doi.org/10.9770/jssi.2019.9.1(2)

JEL Classifications: F52, O39

\section{Introduction}

Market economy conditions require a constant search for new ideas, opportunities, and orientation towards innovation. The development of any system becomes possible thanks to active investment, finance and activities. However, the great degree of a risk of deterioration of economic safety, and risks that invested funds will not bring the expected results, as well as a lack of own funds, insolvency of customers and unacceptable conditions of investment and lending inhibit the development of enterprises. The economic evaluation of investment, financial and operational activities of the enterprise and output types of risks that allows to comprehensively examine the state of economic safety in order to identify problem situations in its observance and strengthening becomes crucial.

\section{Literature Survey}

The following research studies are devoted to the study of organizational and economic problems of the impact of heterogeneous risks and the advocacy of the economic safety of companies and enterprises (Barton, et al. 2001; Brockett and Rezaee, 2012; Dobelli, 2013; Kaplan and Mikes, 2012; Keynes, 2013; Marilena and Corina, 2012; Ozturk, 2016; Perry, 2017; Tvaronavičienè, 2018; Kuzmin et al. 2019; Cherchyk et al. 2019; Vorotnikov, et al. 2019; Limba et al., 2019). At the same time, the insufficient attention is paid to issues related to the management of the flows of risks of investment, financial and operational origin and the development of methodological recommendations for maintaining a high level of economic safety of the enterprise.

The purpose of the paper is to formulate and test case-based methodological approaches to the search and reduction of the impact of investment, financial and operational risks in order to maintain the company's proper economic safety. 


\section{Methods}

The financial and economic crises affecting the world economy from time to time raise the issue of the need to find methodological tools and practical principles for reduction of the impact of investment, financial and operational risks on business activities of enterprises and prevent the reduction of economic safety. On the one hand, the operational activities set the task for investment activities, since the need to increase the competitiveness of an enterprise requires investment. At the same time, the necessary sources of investment can be attracted through financial activities (Nikitina et al. 2018; Shvetsova et al. 2018; Masood et al. 2019).

\section{Results}

On the other hand, it is investment activities are a preliminary step for the organization of the main activities of the enterprise (Fig. 1).

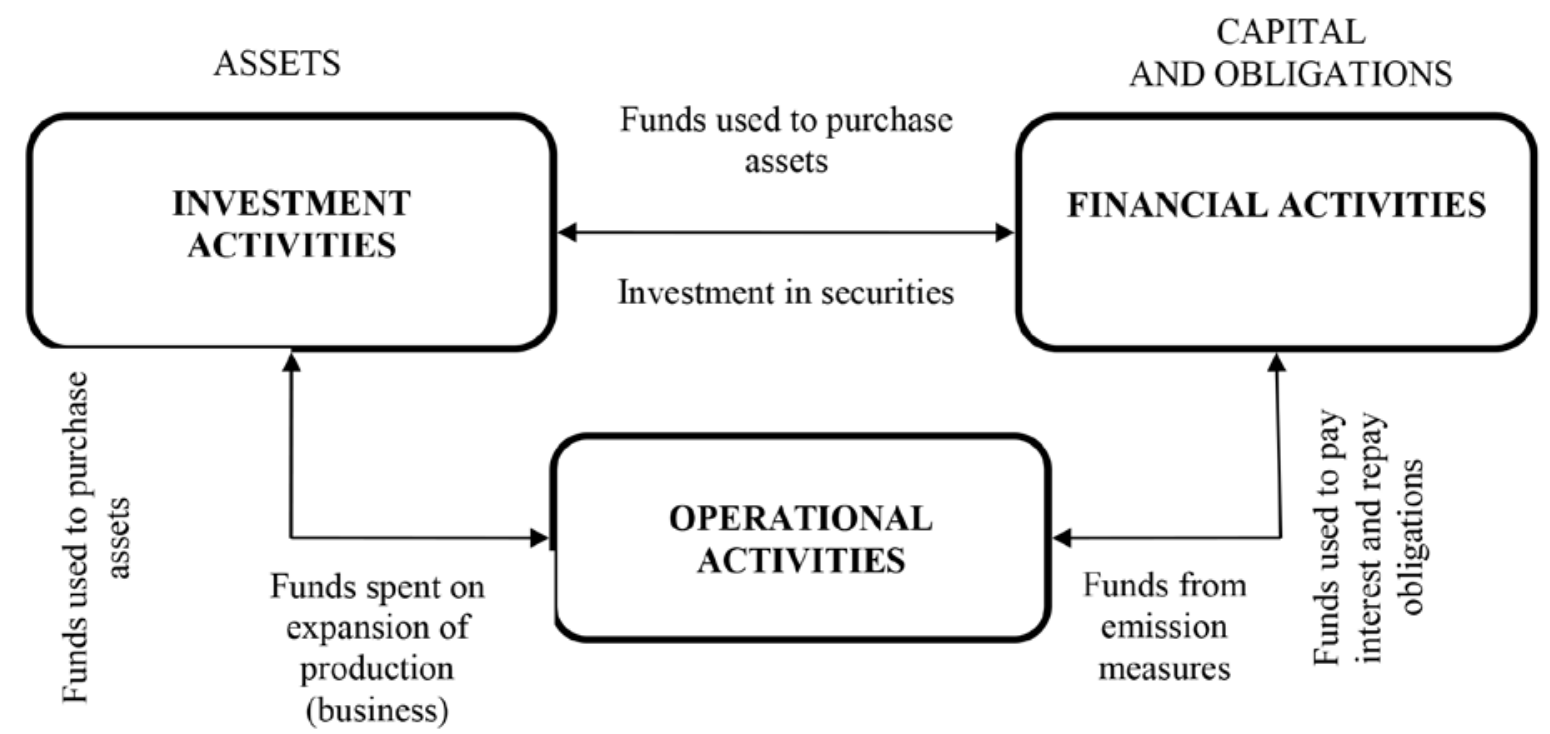

Fig. 1. Scheme of interaction of investment, financial and operational activities of the enterprise

Source: Dobson and Bertels, 2017

So, we form an updated concept of investment activities in industry, which is a strategic set of consistent actions when investing funds and resources to stimulate investment activities in order to obtain competitive advantages or obtain the benefits in some form in the future period based on a market approach, taking into account the conditions of production and prevention of violation of the safety of the business entity (Dykha M. V., 2016).

The attraction of investments, the use of investment resources will increase the risk-protection of enterprises, which will promote the restoration of the reproductive process in industry and the safety of existence. This approach entails obligatory consideration of the economic essence of the activities as an investment-innovation ones. The investment-innovation activities in industry are connected with investment in the production of innovations, that is, a systematic and consistent process of implementation of innovation-investment projects, stimulation of investment activities of economic entities in order to provide competitive advantages in the forecast period (based on market orientation) (Gitman \& Joehnk 2011).

The main objective of the operational, investment and financial activity in the industry should be to create the optimal conditions for the development and intensification of the use of innovative potential based on investments. The main principles of operational, investment and financial activities in industry are purposefulness, unity, mutual influence, movement, adaptability, knowledge, efficiency, multivariateness, systemicity, regulation of actions, complexity, social, ecological and economic safety. 
The purposefulness involves directed investments in order to obtain an effect in a certain time period. The efficiency implies extraction of profit and (or) other effect. The multivariateness is possible when evaluating the efficiency of investments. The systemacity implies a certain investment process algorithm. The controllability of actions means the ability to influence investment activities. The complexity allows the use of various methods and techniques for the regulation of operational, investment and financial activities. The social, environmental and economic security is seen as a necessary condition for the implementation and development of enterprises and the challenge of their economic safety (Bertels and Dobson 2017).

It is especially necessary to distinguish the investment activities of enterprises, which forms the largest list of risks to economic activities. The investment activities is the intensity of investments, which is characterized by volumes and rates of attraction of investments and obtaining a socio-economic result with effective use of investments. At the same time, the level of investment attractiveness serves as an integral indicator summarizing the multi-directional impact of investment potential and investment risk indicators (Kruschwitz \& Husmann, 2012).

The investment potential is in the form of an amount of objective prerequisites for investment, which depends both on the diversity of spheres and objects of investment, and on their economic health. Investment potential is a characteristic that takes into account the main macroeconomic characteristics, the territory's saturation with factors of production, consumer demand of the population, other indicators. The structure of investment potential includes the following components: resource and raw material potential; production potential; consumer potential; infrastructure potential; labour potential; institutional capacity; financial potential; innovative potential; intellectual potential, and marketing potential (Karpenko et al., 2018).

In relation to investments, the investment climate shows the extent to which a favourable situation can be favourable and unfavourable. The favourable investment climate promotes active activity of the investor and stimulates the inflow of capital (Fig. 2).
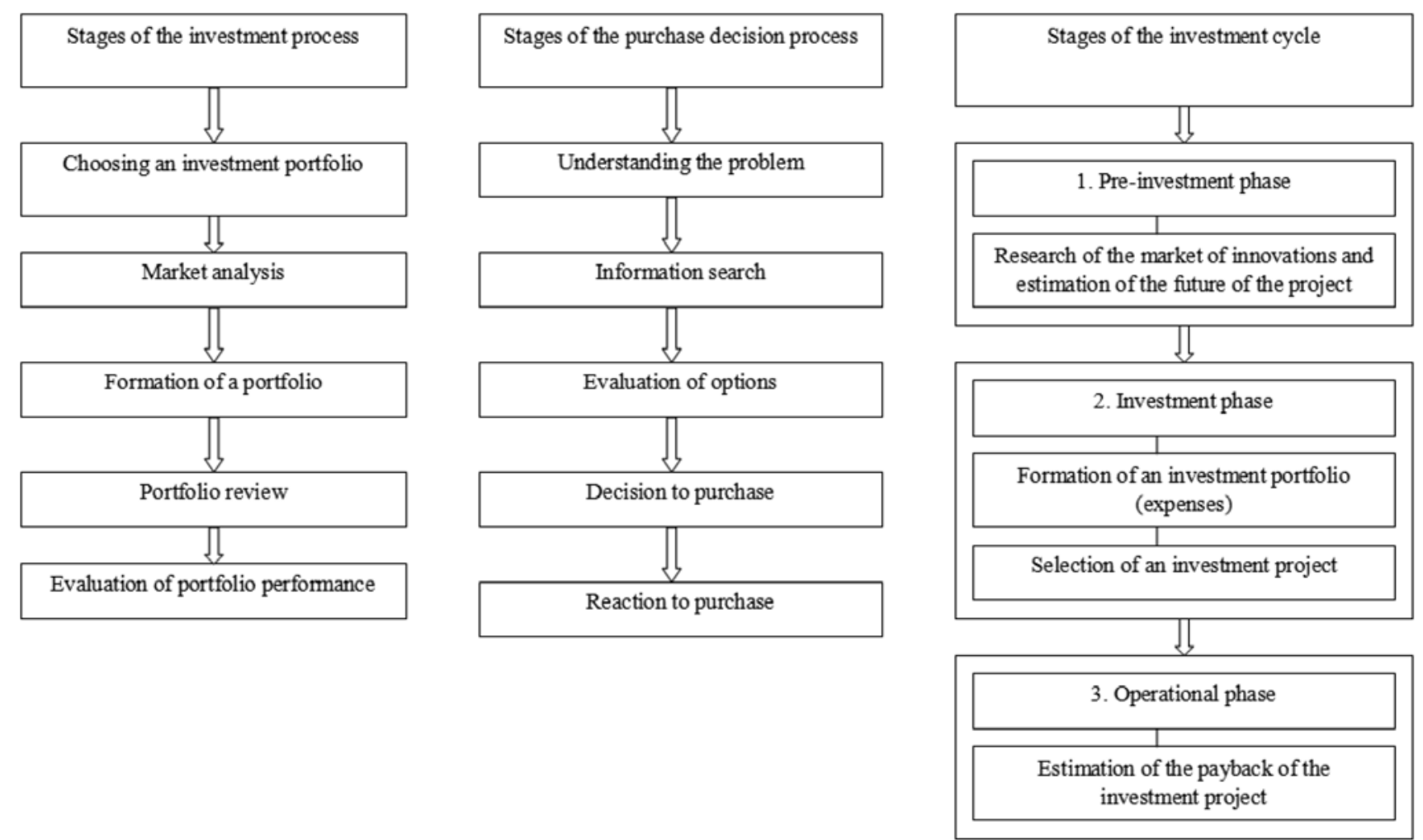

Fig. 2. Stages of the investment process at the enterprise 
An unfavorable investment climate means an increase in risk for an investor, which in turn leads to capital leakage and a decline in investment activity. The investment risk reflects the feasibility of investment in this territory, the probability of loss of investment and income from them. The investment risk is a qualitative aspect of investment attractiveness and is subdivided into: economic, social, political, financial, ecological, and criminal (Tetiana et al., 2018). We consider it important, when considering investment activity, to introduce the notion of an investment complex.

The investment complex should be understood as the integral combination of organizations belonging to one (related) industry, related to each other by economic relations in the field of production and distribution of products, goods, services in a specific market segment (territory) with a view to optimize the use and distribution of investment resources (Dudzevičiūtè and Prakapienè, 2018). Factors influencing investment and innovation activity are subdivided, based on the possibility of influence on them by the company, into objective and subjective ones (Fig. 3).

The subjective factors are related to management activities. Considering investment and innovation activities as a complex multi-level multifunctional economic system, it is necessary to use in its formation and development the directions of its activities, which ensure its systemic rationality. The links between subjects and objects of investment and innovation activities are diverse. It is necessary to distinguish between them system-forming connections and to reveal the nature of their manifestation in the direction of development of the investment activity itself. The main directions of investment activities are measures to organize a favourable regime for activities of domestic and foreign investors, increase profitability and minimize risks in the interests of stable socio-economic development and raising the standard of living of the population. The result of the investment activities is the volume of involvement in the development of the industry and organization of investment resources (Teletov et al., 2017).

The mechanisms of control and ongoing management of investment, financial and operational risks, and overcoming the pressure on the company's economic safety will be conducted on the bases of the case-by-case basis through the introduction of Case-Enterprise - (Public Joint Stock Company) PJSC Company A" for modelling the parameters of scientific research. Under the investment, financial and operational risks at PJSC Company A, we understand the probability of losses of a number of production assets during the active phase of production. During the risk management procedures at the enterprise, it analyzes the sources of risks, performs the ongoing monitoring, assesses their importance and level of threats, and controls the qualitative components of these risks (Bordens, 2006; Lake, et al., 2016).

The mechanism for monitoring of investment and operational risks at PJSC Company "A" aims at achievement of the following objectives:

- risks should be controlled and analytically justified by the management of the enterprise;

- the risks should be in the intervals of certain tolerances determined expertly and have a map of compliance with them;

- the package of decisions regarding the acceptance of permissible risks should correspond to the strategic map of balanced indicators of the enterprise;

- decisions on the admission of the occurrence of certain types of risks should be agreed upon and justified at the highest level of management;

- the expected set of economic benefits must fully compensate for the risks inherent in the system;

- motivational components for achievement of significant profitability indicators must pass obligatory acceptance of the permissible level of risk.

The second step of our analysis is to determine the parameters of the already existing system of risk management of the investigated enterprise. This system provides a series of tasks and processes (COSO, 2017; Paseková et al., 2017):

- balance the ratio of forecasted risks, potential, capital and production growth rates;

- reduce uncertainty when making investment decisions; 
- reduce starting conditions and thresholds of investment and production risks to a minimum;

- to introduce a system of forecasts of the occurrence of certain threats and risks;

- the overall process of reduction of the costs of overcoming risks;

- to improve the system of risk management at the investigated enterprise by introducing a modern control system.

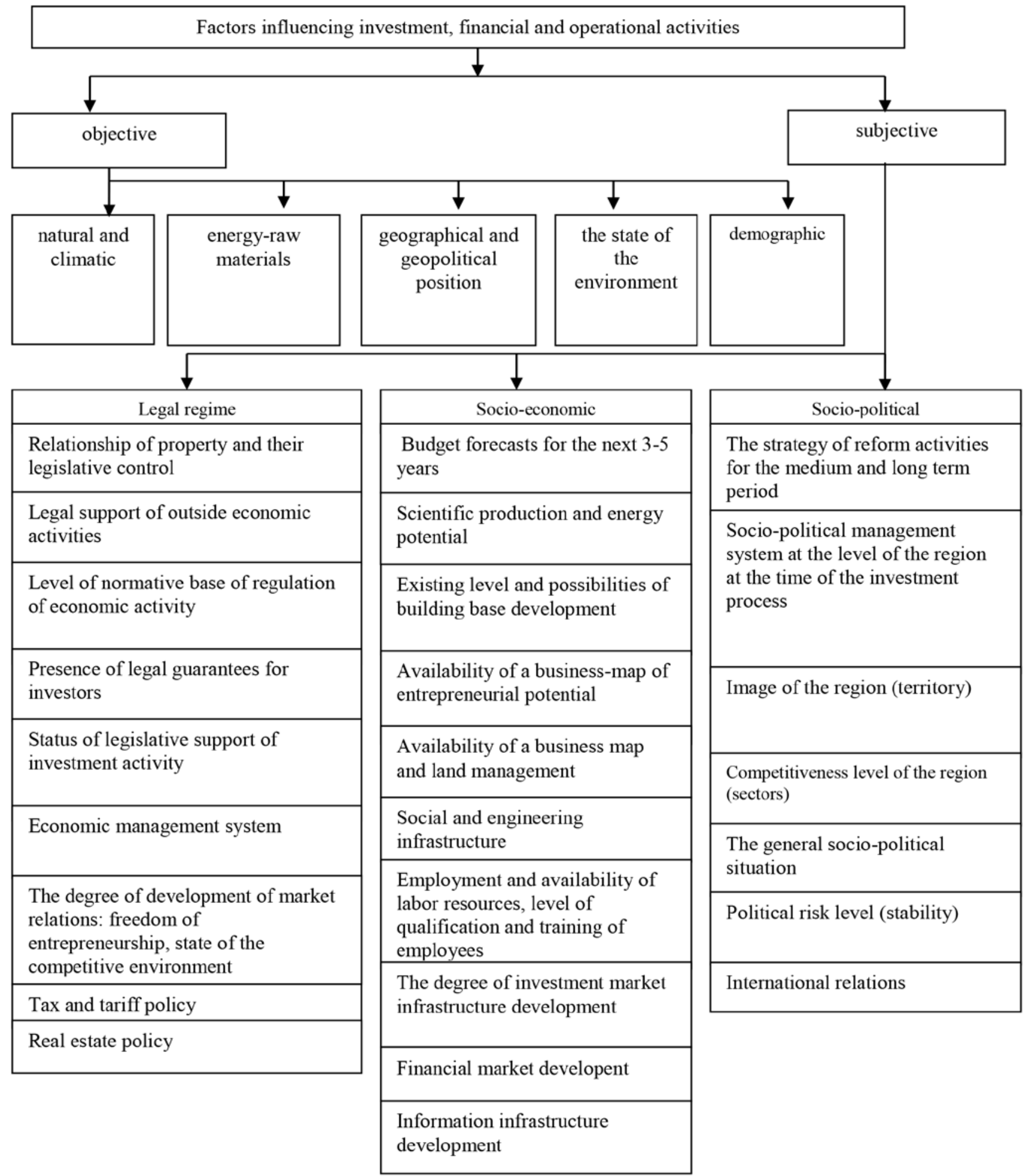

Fig. 3. Factors influencing the investment activity of the enterprise 
The objective factors are the availability of raw materials and climatic conditions. Objective factors restraining the investment activity inherent in the industry: pronounced seasonality of production; long production cycle; slow turnover of investments; high capital intensity of products; natural and climatic factor and demographic factor, etc. (Reischmann, (2016). The processes of risk management at the enterprise absorb all of its levels of management where the conditions of occurrence of those or other risks are constantly formed. The current structure of simplified management of existing risks in the enterprise is presented in Figure 4.

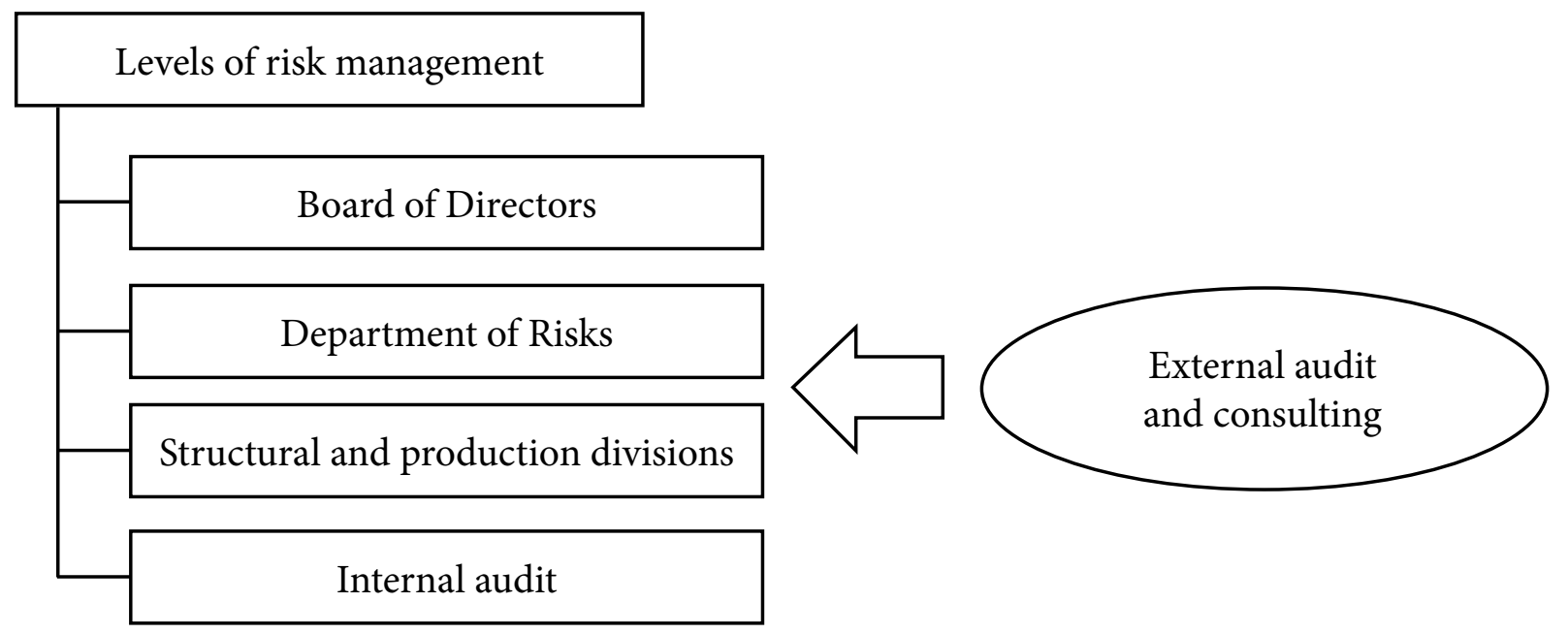

Fig. 4. Structure of current risk management at the PJSC Company A.

Source: Designed by the authors

The economic operations of the investigated enterprise, like any other enterprise, accompany significant volumes of production and financial risks, the lateness of which reveals the consequences of production losses and fluctuations (Ignatavičius, et al., 2015). Table 1 lists the main types of damages and losses and factors of these risks, all of which were identified analytically and by expert estimates.

Risk factors that originate from the environment, and this is primarily a macro environment and, of course, the internal environment. All factors are divided into three levels.

Table 1. System risks of investment, financial and operating activities of PJSC Company "A", million Euro (analytical model)

\begin{tabular}{|c|c|c|c|}
\hline Description of losses & Risk factor & $\begin{array}{l}\text { Source (macro, micro, } \\
\text { internal environment) }\end{array}$ & $\begin{array}{c}\text { Amount of } \\
\text { damages, } \\
\text { million euros }\end{array}$ \\
\hline 1 & 2 & 3 & 4 \\
\hline \multicolumn{4}{|c|}{ Production } \\
\hline 1. The cost of removal of defects & Violation of technology & Internal environment & 2.68 \\
\hline $\begin{array}{l}\text { 2. Fines for untimely execution of } \\
\text { works }\end{array}$ & Lack of production personnel & Internal environment & 0.25 \\
\hline $\begin{array}{l}\text { 3. Losses from extension of } \\
\text { production deadlines }\end{array}$ & $\begin{array}{l}\text { Unsatisfactory preparation } \\
\text { of production }\end{array}$ & Internal environment & 2.68 \\
\hline 4. Over expenses for salary payment & Weak organization of work & Internal environment & 6.58 \\
\hline 5. Downtimes & Uneven loading & Microenvironment & 6.74 \\
\hline \multicolumn{4}{|c|}{ Finances } \\
\hline $\begin{array}{l}\text { 6. Expenses for payment of additional } \\
\text { interest for using a loan }\end{array}$ & Exceeding the planned inflation rate & Macro environment & 0.3 \\
\hline 7. Payment of fines to creditors & Untimely payments & Internal environment & 0.01 \\
\hline
\end{tabular}




\begin{tabular}{|c|c|c|c|}
\hline $\begin{array}{l}\text { 8. Costs of crediting working capital } \\
\text { shortages }\end{array}$ & Untimely receipts from debtors & Microenvironment & 3.1 \\
\hline \multicolumn{4}{|c|}{ Energy sales } \\
\hline 9. No income for additional work & Untimely registration & Microenvironment & 4.26 \\
\hline $\begin{array}{l}\text { 10. Refusal of the customer from the } \\
\text { contract }\end{array}$ & Untimely execution of the contract & Microenvironment & 121 \\
\hline $\begin{array}{l}\text { 11. Refusal of the customer to accept } \\
\text { work }\end{array}$ & Inadequate legal support & Internal environment & 1 \\
\hline $\begin{array}{l}\text { 12. Uneven loading of existing } \\
\text { capacities }\end{array}$ & $\begin{array}{l}\text { Bad awareness of the needs of } \\
\text { production, the lack of necessary } \\
\text { market proposals }\end{array}$ & $\begin{array}{l}\text { Internal environment } \\
\text { Microenvironment }\end{array}$ & 51.4 \\
\hline \multicolumn{3}{|c|}{ In general: } & 200 \\
\hline
\end{tabular}

Source: calculated by the authors

At the first level, we lay out those types of risks that the investigated enterprise can not fully control. These are the risks of economic, political, demographic, scientific and technical natural and cultural origin (Čirjevskis, 2016).

At the second level, we place the types of risks that are generated by competitors, suppliers, and consumers. The enterprise can influence their activities to a certain extent and in certain circumstances.

At the third level, we lay out the types of risks that are generated by the internal environment and are fully controlled: production, investment, innovation finance, personnel, etc. To identify risk factors, we use a risk analysis matrix. We will present the results of the study in Table 2.

Table 2. Risk Analysis Matrix of PJSC Company A (Analytical Model)

\begin{tabular}{|c|c|c|c|c|c|c|c|c|c|c|c|c|c|c|}
\hline \multirow{2}{*}{$\begin{array}{l}\text { Sources } \\
\text { of Risks }\end{array}$} & \multicolumn{6}{|c|}{ Macro environment } & \multicolumn{3}{|c|}{ Micro environment } & \multicolumn{5}{|c|}{ Internal environment } \\
\hline & : & 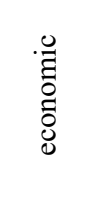 & 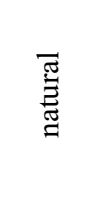 & $\frac{\bar{T}}{\underline{E}}$ & 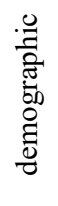 & 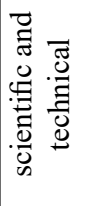 & 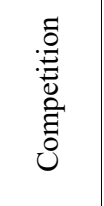 & 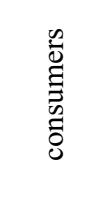 & 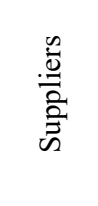 & 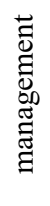 & 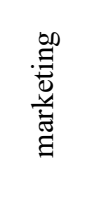 & 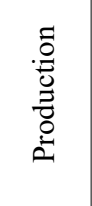 & 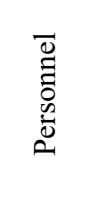 & $\begin{array}{l}\mathscr{\circlearrowright} \\
\stackrel{\Xi}{\Xi} \\
\stackrel{\Xi}{\Xi}\end{array}$ \\
\hline Management & - & - & - & - & - & - & - & - & - & - & - & - & $\begin{array}{l}\text { DR_1 } \\
\text { DR_2 }\end{array}$ & - \\
\hline Production & - & - & PR_1 & - & - & PR_2 & - & - & - & - & PR_3 & - & PR_4 & PR_5 \\
\hline Finances & FR_1 & FR_2 & - & - & - & - & - & FR_3 & FR_4 & - & - & FR_5 & - & - \\
\hline Marketing & MR_1 & - & - & - & - & - & MR_2 & MR_3 & MR_4 & - & - & - & - & - \\
\hline Fixed assets & - & - & RF_1 & - & - & - & - & - & - & - & - & - & - & - \\
\hline Quality & - & - & - & - & - & - & - & - & - & - & - & YR_1 & - & - \\
\hline Legal & - & - & - & - & - & - & - & - & - & - & - & - & - & YuR_1 \\
\hline
\end{tabular}

Source: calculated by the authors

We will transfer all types of risks identified by us in the enterprise to table 3 according to the work of each level. The top managers and managers of the middle management were appointed as the experts. We evaluate the consequences of states, probability and quality of management using a nine-point scale from three levels of assessment (Allianz, 2018). For analysis we will have: little serious (1-3), moderate (4-6); serious (7-9 points). For event probability: low probability (1-3); average probability (4 6); high probability (7-9). For management quality: low quality (7-9); average quality (4 -6); high quality (1-3). 
Table 3. The summary table of assessments of investment, financial and operational risks and risks identified by experts for PJSC Company A (analytical model)

\begin{tabular}{|c|c|c|c|c|c|c|c|}
\hline \multirow[b]{2}{*}{$\begin{array}{l}\text { Risk } \\
\text { code }\end{array}$} & \multirow[b]{2}{*}{ Formulation of a risk } & \multirow{2}{*}{$\begin{array}{c}\text { The } \\
\text { magnitude } \\
\text { of the } \\
\text { possible } \\
\text { damage, } \\
\text { million } \\
\text { euros }\end{array}$} & \multirow[b]{2}{*}{ Risk factor } & \multicolumn{4}{|c|}{ Balance risk assessment: } \\
\hline & & & & $\begin{array}{l}\text { Event } \\
\text { proba- } \\
\text { bility }\end{array}$ & $\begin{array}{c}\text { Event } \\
\text { conse- } \\
\text { quences }\end{array}$ & $\begin{array}{l}\text { Risks } \\
\text { mana- } \\
\text { gement } \\
\text { quality }\end{array}$ & $\begin{array}{c}\text { Integral } \\
\text { score } \\
(5+6+7)\end{array}$ \\
\hline DR_1 & $\begin{array}{l}\text { Losses from the low quality of the } \\
\text { management system }\end{array}$ & 1,000 & $\begin{array}{l}\text { Low qualification of } \\
\text { managerial staff }\end{array}$ & 9 & 1 & 7 & 17 \\
\hline DR_2 & $\begin{array}{l}\text { Losses from improper performance of } \\
\text { managerial decisions }\end{array}$ & 1,000 & Low labour discipline & 9 & 1 & 7 & 17 \\
\hline PR_1 & $\begin{array}{l}\text { The risk of decrease in the amount of work } \\
\text { to be done }\end{array}$ & 1,000 & $\begin{array}{l}\text { Particularly adverse weather } \\
\text { conditions }\end{array}$ & 4 & 1 & 9 & 14 \\
\hline PR_2 & $\begin{array}{l}\text { Risk of loss of competitiveness by terms of } \\
\text { repair }\end{array}$ & 2,000 & $\begin{array}{c}\text { Lack of technical } \\
\text { innovations compared to } \\
\text { competitors }\end{array}$ & 7 & 2 & 7 & 16 \\
\hline BP_3 & Risk of downtime & 1,000 & $\begin{array}{l}\text { Uneven loading of } \\
\text { production }\end{array}$ & 7 & 1 & 5 & 13 \\
\hline BP_4 & $\begin{array}{l}\text { Risk of income loss due to lack of } \\
\text { production personnel }\end{array}$ & 6,000 & $\begin{array}{l}\text { Insufficient number of } \\
\text { production personnel }\end{array}$ & 8 & 6 & 7 & 21 \\
\hline PR_5 & $\begin{array}{l}\text { Risk of sanctions for late execution of } \\
\text { works }\end{array}$ & 1,000 & $\begin{array}{l}\text { Worker strikes due to salary } \\
\text { debts }\end{array}$ & 7 & 1 & 5 & 13 \\
\hline FR_1 & Risk of increase in tax expenses & 1,770 & $\begin{array}{l}\text { Cancellation of the } \\
\text { land tax exemption }\end{array}$ & 7 & 2 & 9 & 18 \\
\hline FR_2 & Risk of increase in financial expences & 750 & Increase in lending rate $5 \%$ & 7 & 1 & 9 & 17 \\
\hline FR_3 & $\begin{array}{l}\text { Risk of loss due to non-payment for work } \\
\text { perfomed }\end{array}$ & 1,000 & $\begin{array}{l}\text { Unsatisfactory paying } \\
\text { capacity of consumers }\end{array}$ & 5 & 1 & 5 & 11 \\
\hline FR_4 & Risk of losses through suppliers & 1,000 & $\begin{array}{l}\text { Untimely or poor quality } \\
\text { delivery }\end{array}$ & 3 & 1 & 5 & 9 \\
\hline FR_5 & Risk of over-planned variable costs & 1,000 & $\begin{array}{l}\text { Low quality of planning and } \\
\text { control in production }\end{array}$ & 8 & 1 & 5 & 14 \\
\hline MR_1 & $\begin{array}{l}\text { Risk of loss from reduction of market } \\
\text { volume }\end{array}$ & 10,000 & $\begin{array}{l}\text { Introduction of unfavorable } \\
\text { customs clearence rules }\end{array}$ & 1 & 7 & 9 & 17 \\
\hline MR_2 & $\begin{array}{l}\text { Risk of loss from reduction in a market } \\
\text { share }\end{array}$ & 2,500 & $\begin{array}{l}\text { Unpredictable actions by } \\
\text { competitors }\end{array}$ & 2 & 3 & 7 & 12 \\
\hline MR_3 & The risk of customer rejection from orders & 2,500 & High price & 5 & 3 & 5 & 13 \\
\hline MR_4 & $\begin{array}{l}\text { Risk of deterioration of payment conditions } \\
\text { and price changes }\end{array}$ & 2,500 & $\begin{array}{l}\text { The worsening of the } \\
\text { market situation, untimely } \\
\text { payment }\end{array}$ & 5 & 3 & 6 & 14 \\
\hline RF_1 & The risk of loss or damage to the FA & 100,000 & Natural disasters & 1 & 9 & 9 & 19 \\
\hline YR_1 & The risk of loss from regection & 2,500 & $\begin{array}{l}\text { Disadvantages in } \\
\text { tecnological support and } \\
\text { weak control }\end{array}$ & 6 & 3 & 5 & 14 \\
\hline YuR_1 & $\begin{array}{l}\text { Risk of loss from sanctions for late } \\
\text { fulfillment of financial obligations }\end{array}$ & 2,000 & $\begin{array}{l}\text { Lack of funds to fulfill all } \\
\text { obligations }\end{array}$ & 9 & 2 & 5 & 16 \\
\hline
\end{tabular}

Source: calculated by the authors

Within the scope of the study, we will range the identified risks and form a map for these risks (Belás, et al., 2017). We will calculate the factors of importance for the group of factors using the data in Table 3 :

- the influence of macroeconomic factors on the level of losses is determined as a factor - 0.3 million euros or 0.0015 ;

- the influence of microeconomic factors on the level of losses is determined as a factor - 131.7 million euros or 0.6585 ; 
- the influence of internal-and-organization factors on the level of losses is determined as a factor - 68 million euros or 0.34 ;

At the final stage, we will multiply the coefficient of importance of the group of factors in order to obtain the resulting integral estimates for risks. The results are presented in Table 4.

Table 4. The summary table of assessments of investment, financial and operational risks and risks identified by experts for PJSC Company A (analytical model)

\begin{tabular}{|c|c|c|c|c|}
\hline Name of a risk & $\begin{array}{c}\text { Integral } \\
\text { score }\end{array}$ & The source of a risk & $\begin{array}{l}\text { Coefficient of } \\
\text { significance }\end{array}$ & $\begin{array}{l}\text { Final } \\
\text { score }\end{array}$ \\
\hline Losses from the low quality of the management system & 17 & Internal environment & 0.34 & 5.78 \\
\hline Losses from improper performance of managerial decisions & 17 & Internal environment & 0.34 & 5.78 \\
\hline The risk of decrease in the amount of work to be done & 14 & Macro environment & 0.0015 & 0.02 \\
\hline Risk of loss of competitiveness by terms of repair & 16 & Macro environment & 0.0015 & 0.02 \\
\hline Risk of downtime & 13 & Internal environment & 0.34 & 4.42 \\
\hline Risk of income loss due to lack of production personnel & 21 & Internal environment & 0.34 & 7.14 \\
\hline Risk of sanctions for late execution of works & 13 & Internal environment & 0.34 & 4.42 \\
\hline Risk of increase in tax expenses & 18 & Macro environment & 0.0015 & 0.03 \\
\hline Risk of increase in financial expenses & 17 & Macro environment & 0.0015 & 0.03 \\
\hline Risk of loss due to non-payment for work performed & 11 & Microenvironment & 0.6585 & 7.24 \\
\hline Risk of losses through suppliers & 9 & Microenvironment & 0.6585 & 5.93 \\
\hline Risk of over-planned variable costs & 14 & Internal environment & 0.34 & 4.76 \\
\hline Risk of loss from reduction of market volume & 17 & Macro environment & 0.0015 & 0.03 \\
\hline Risk of loss from reduction in a market share & 12 & Microenvironment & 0.6585 & 7.90 \\
\hline The risk of customer rejection from orders & 13 & Microenvironment & 0.6585 & 8.56 \\
\hline Risk of deterioration of payment conditions and price changes & 14 & Microenvironment & 0.6585 & 9.22 \\
\hline The risk of loss or damage to the FA & 19 & Macro environment & 0.0015 & 0.03 \\
\hline The risk of loss from regection & 14 & Internal environment & 0.34 & 4.76 \\
\hline Risk of loss from sanctions for late fulfillment of financial obligations & 16 & Internal environment & 0.34 & 5.44 \\
\hline
\end{tabular}

Source: calculated by the authors

Let's choose the risks with the highest values of the final estimation being guided by the Pareto principle $20-25 \%$ of the risks with the highest values of the final evaluation, that is: MR 4 - risk of deterioration of payment terms and price changes (9.22); MR_3 - the risk of a customer's refusal from orders $(8,56)$; MR_ 2 - risk of loss from a decrease in the market share (7.9); FR_3 - risk of loss due to non-payment of work (7,24); PR_4 risk of loss of income due to lack of production personnel $(7,14)$; FR_ 4 - risk of loss through suppliers (5.93).

We will compile a summary chart of the groups of risks (Table 5).

Table 5. The map of investment, financial and operational risks and risks identified

by experts for PJSC Company A (analytical model)

\begin{tabular}{|l|c|c|c|}
\hline High & & & \\
\hline Medium & & & BP_4 \\
\hline Low & MR_2, FR_4 & MR_4, MR_3, FR_3 & \\
\hline Severity of the consequences & Low & Medium & High \\
\hline
\end{tabular}

Source: calculated by the authors 
So, we have obtained the result that the system of management of investment and production risks at the enterprise PJSC Company " $\mathrm{A}$ " is sufficiently effective and has an independent structure indicating the possibilities of forecasting risks, processing of operational information with the aim of making advance decisions on macro and microeconomic events.

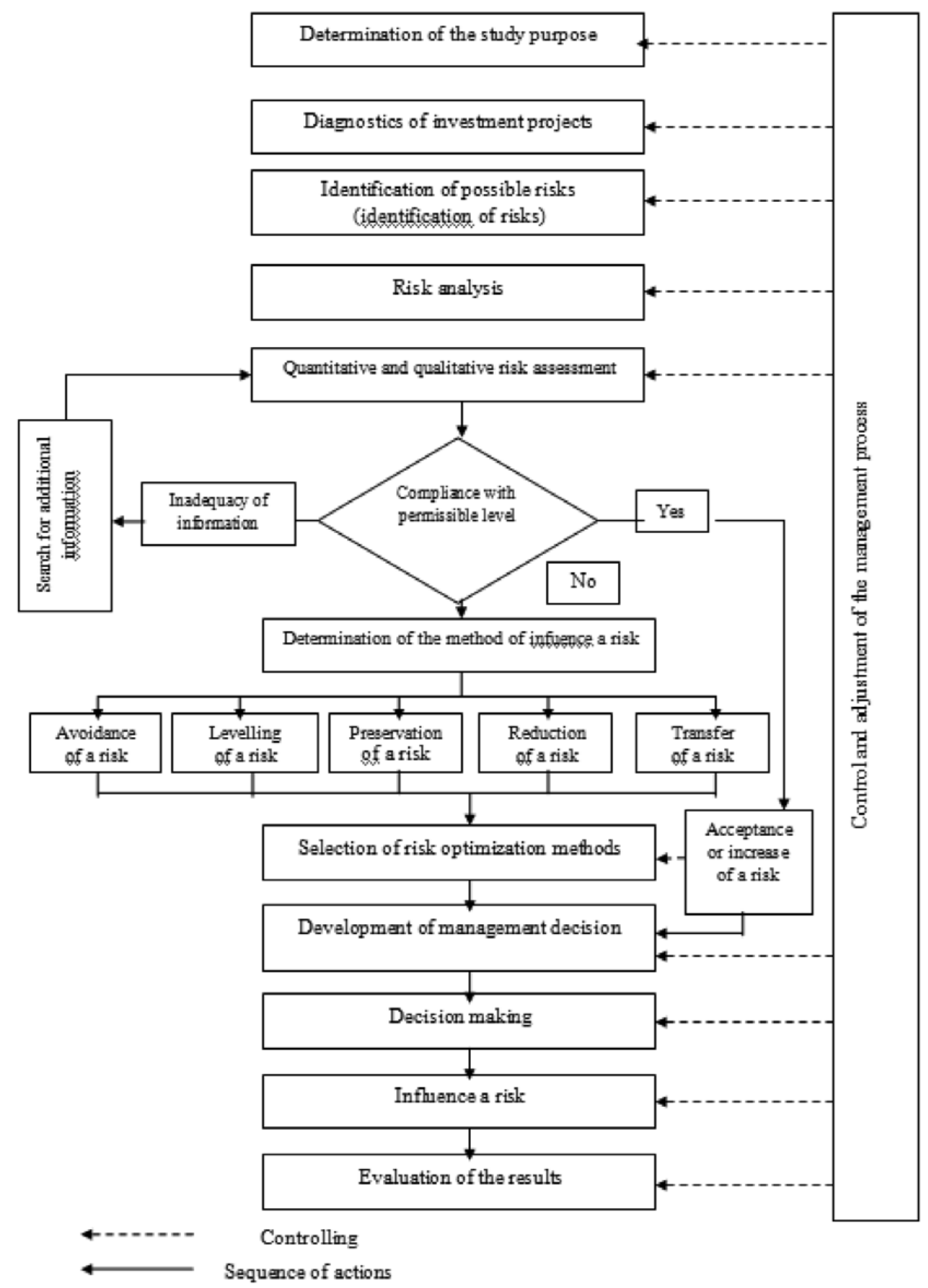

Fig. 5. Stages of implementation of the process of management of investment, financial and operational risks of the enterprise Source: Designed by the authors 
But on the other hand, the analysis showed that the system is not working thoroughly, there is a large number of production, innovation and investment risks, and this is seen from the fact that the investigated company received losses of more than 200 million euros. This gives us grounds to start development of measures on provision of support of investment activities of the enterprise, which will minimize the whole list of risk identified.

Taking into account the fact that one of the main risks for PJSC Company "A" was the risk associated with investment and production contracts, there is a need to allocate those risks that should become a priority of measures for the economic safety of the enterprise under investigation in the mechanism of combating the risks. Let'us determine more substantially the main and determining stages of risk management at PJSC Company "A".

At the first stage of risk management it will be advisable to evaluate the state of affairs in the field of production. At the diagnostic stage, the management of an enterprise should gather information about the properties and structure of the object of the risk studied, identify the strategic and tactical objectives of the measures, analyse the situation and prospects of the development of the situation and the impact of the external environment (Fig. 5).

\section{Discussion}

After that, we can formulate the necessary methods for managing investment, financial and operational risks, which were determined by the results of the survey (MSCI, 2018). The methods of risk management, which estimates have the most impact are presented in the table (Table 6).

Table 6. The offered methods of risk management at PJSC Company A (model)

\begin{tabular}{|c|c|c|c|}
\hline Risk / Possible damage & $\begin{array}{l}\text { Methods } \\
\text { of influence }\end{array}$ & Direction of influence & $\begin{array}{l}\text { Funds for implementation } \\
\text { of this method of risk } \\
\text { management / Coefficient of } \\
\text { economic efficiency }\end{array}$ \\
\hline $\begin{array}{l}\text { 1. Risk of income loss due to lack of } \\
\text { production personnel }\end{array}$ & $\begin{array}{l}\text { Reduction of the size } \\
\text { of the damage }\end{array}$ & $\begin{array}{l}\text { Conduct a series of organizational } \\
\text { recruitment activities }\end{array}$ & No additional expenses \\
\hline $\begin{array}{l}\text { 2. MR_4 - risk of deterioration } \\
\text { of payment terms and changes in } \\
\text { supplier prices } / 2,500\end{array}$ & Prevention of damage & Diversification of suppliers & No additional expenses \\
\hline $\begin{array}{l}\text { 3. MR } 3 \text { - the risk of a customer's } \\
\text { refusal from orders } / 2,500\end{array}$ & $\begin{array}{l}\text { Reduction of the size } \\
\text { of the damage }\end{array}$ & $\begin{array}{c}\text { Reduced production costs and } \\
\text { increased cost control and production } \\
\text { organization }\end{array}$ & No additional expenses \\
\hline $\begin{array}{l}\text { 4. FR_3 - risk of loss due to non- } \\
\text { payment for works/ } 1,000\end{array}$ & $\begin{array}{l}\text { Prevention of } \\
\text { damages and } \\
\text { reduction of their size }\end{array}$ & $\begin{array}{l}\text { studying paying capacity of the } \\
\text { customer, use of factoring }\end{array}$ & $\begin{array}{l}\text { Factoring - from } 2 \text { to } 50 \% \\
\text { of the amount receivable }\end{array}$ \\
\hline $\begin{array}{l}\text { 5. MR_2 Risk of loss from reduction } \\
\text { in a market share }\end{array}$ & Prevention of damage & $\begin{array}{l}\text { Constant monitoring and forecasting of } \\
\text { competitors }\end{array}$ & No additional expenses \\
\hline $\begin{array}{l}\text { 6. FR_4 - Loss risk through } \\
\text { suppliers } / 1,000\end{array}$ & $\begin{array}{l}\text { Prevention } \\
\text { of damage }\end{array}$ & $\begin{array}{l}\text { Strengthening of control over } \\
\text { compliance by suppliers with } \\
\text { contractual terms, imposition of } \\
\text { penalties in contracts that are adequate } \\
\text { to possible damages }\end{array}$ & \\
\hline \multicolumn{4}{|l|}{ Total: 15,500 million euros } \\
\hline Economic eficiency factor: & $15,500 / 500=31$ & & \\
\hline
\end{tabular}

Source: calculated by the authors

At the very beginning, one should determine the most probable and complex risks that, over time, become more predictable, and the portfolio of future risks shall be formed on this basis. The procedure for diagnosing risks can take place through the use of a set of formal and informal approaches and methods based on the introduction of information of a subjective or objective origin. The current amount of information will suffice to make expert decisions at the next stages of the risk management system (Li, et al., 2017). For a risk of type BP_4, which is defined as the risk of loss of potential income due to the lack of production personnel, we propose a 
method of reduction of the amount of losses through the implementation of incentive measures for the labour force who obtains education in the professional institutions of the region or area where the units of PJSC Company "A" are operating and there is the possibility of full-fledged contracts for the training of specialists.

\section{Conclusions}

At PJSC Company A, we can state the chronic and permanent shortage of skilled workforce (operational risks) that has special knowledge and skills. This leads to the company being forced to refuse to execute a number of projects and orders in the main field of economic activity, which will greatly affect the investment and innovation attractiveness, and hence the level of economic safety. On this basis, we have failures in the timing of the work, which ultimately leads to financial losses and badly affects the competitive status of the company's safety. Consequently, we can conclude that the work with a number of risks may not require significant costs, but in case of levelling out these risks, new effects can create conditions for stabilizing the financial state of the case company and its gradual development to the lossless level of work.

Previous analytical calculations and methodological summaries have shown that the effectiveness of the risk management system produces an integral risk factor for the entire investigated enterprise in the amount of 31 units, from which it follows that each conventional monetary unit that we can spend on managing a certain range of risks of the investigated enterprise can save 31 euros, possible losses for every 1,000 euros money units for investment in production and material development. So, we have received an effective methodological approach to detect and reduce the impact of investment, financial and operational risks on the company's economic security.

\section{References}

Allianz. (2018). Allianz Risk Barometer: Top Business Risks for 2018. Retrieved from Allianz: https:/www.agcs.allianz.com/assets/ PDFs/Reports/Allianz_Risk_Barometer_2018_EN.pdf

Astakhova, J. (2012). Modern Approaches to Accounting of Financial Instruments. Accounting and Statistics.

Barton, Thomas L., William G. Shenkir, and Paul L. Walker, (2001). Making Enterprise Risk Management Pay Off, Financial Executives Research Foundation, Upper Saddle River, N.J.

Belás, J.; Mišanková, M.; Schönfeld, J.; Gavurová, B. (2017). Credit risk management: financial safety and sustainability aspects, Journal of Security and Sustainability Issues 7(1): 79-93. https://doi.org/10.9770/jssi.2017.7.1(7)

Bertels, S., Dobson, R. (2017). The Road to Context: Contextualising Your Strategy and Goals. Retrieved from Embedding Project: https://embeddingproject.org/resources/the-road-to-context

Bordens, K. (2006). Research Design \& Methods. New Delhi: Tata McGraw-Hill.

Brockett, A.; Rezaee, Z. (2012). Corporate Sustainability: Integrating Performance and Reporting. New Jersey, USA: Willey

Cherchyk, L.; Shershun, M.; Khumarova, N.; Mykytyn, T.; Cherchyk, A. 2019. Assessment of forest enterprises' performance: integrating economic security and ecological impact, Entrepreneurship and Sustainability Issues 6(4): 1784-1797. http://doi.org/10.9770/ jesi.2019.6.4(17)

Čirjevskis, A. (2016). Sustainability in information and communication technologies' industry: innovative ambidexterity and dynamic capabilities perspectives, Journal of Security and Sustainability Issues 6(2): 211-226. http://dx.doi.org/10.9770/jssi.2016.6.2(2)

COSO (2017, June). Enterprise Risk Management: Integrating with Strategy and Performance. p. 72

Dobelli, R. (2013). The Art of Thinking Clearly. HarperCollins.

Dobson, R. and Bertels, S. (2017). The Road to Context: Contextualising your Strategy \& Goals Casebook. Embedding Project

Dudzevičiūte, G.; Prakapienè, D. (2018). Investigation of the economic growth, poverty and inequality inter-linkages in the European Union countries, Journal of Security and Sustainability Issues 7(4): 839-854 https://doi.org/10.9770/jssi.2018.7.4(19) 
Dykha M. V. (2016). Sotsialno-ekonomichnyi rozvytok Ukrainy: napriamy ta zasoby realizatsii: [monohrafiia] / M. V. Dykha. - K.: Tsentr uchbovoi literatury, 2016. - 388 s. http://elar.khnu.km.ua/jspui/handle/123456789/5964

Eckbo, B. E. (2007). Handbook of corporate finance. Elsevier/North-Holland.

Gitman, L. J., \& Joehnk, M. D. (2011). Fundamentals of Investing. Prentice Hall.

Ignatavičius, R.; Tvaronavičienė, M.; Piccinetti, L. (2015). Sustainable development through technology transfer networks: case of Lithuania, Journal of Security and Sustainability Issues 4(3): 261-267. https://doi.org/10.9770/jssi.2015.4.3(6)

Kaplan, R. and Mikes, A. (2012)). Strategic Planning: Managing Risks: A New Framework. Retrieved from Harvard Business Review

Karpenko, L.; Serbov, M.; Kwilinski, A.; Makedon, V. \& Drobyazko, S. (2018). Methodological platform of the control mechanism with the energy saving technologies, Academy of Strategic Management Journal 17(5) URL: https://www.abacademies.org/articles/ Methodological-platform-of-the-control-mechanism-1939-6104-17-5-271.pdf

Keynes, J.M. (2013). The General Theory of Employment, Interest and Money. The Postulates of the Classical Economics. King's College, Cambridge.

Kruschwitz, L., \& Husmann, S. (2012). Financing and investment. The foundations of the modern theory of finance. Revised and expanded edition. Hardcover, Oldenbourg (in German).

Kuzmin, E.A.; Vinogradova, M.V.; Guseva, V.E. 2019. Projection of enterprise survival rate in dynamics of regional economic sustainability: case study of Russia and the EU, Entrepreneurship and Sustainability Issues 6(4):1602-1617. https://doi.org/10.9770/ jesi.2019.6.4(4)

Lake, S., Rosenbarger, A., Winchester, C. (2016). Palm Risk Assessment Methodology: Prioritizing Areas, Landscapes, and Mills. Retrieved from World Resources Institute: http://www.wri.org/sites/default/files/Palm_Risk_Assessment_Methodology_Prioritizing_Areas_Landscapes_And_Mills.pdf

Li, M.; Ning X.L.; Li, M.Z.; Xu, Y.C. (2017). An Approach to the Evaluation of the Quality of Accounting Information Based on Relative Entropy in Fuzzy Linguistic Environments. Entropy, 19(4): 152-168. http://dx.doi.org/10.3390/e19040152

Limba, T.; Stankevičius, A.; Andrulevičius A. 2019. Cryptocurrency as disruptive technology: theoretical insights, Entrepreneurship and Sustainability Issues 6(4): 2068-2080. http://doi.org/10.9770/jesi.2019.6.4(36)

Marilena, Z.; Corina, I. (2012). Embellishment of Financial Statements through Creative Accounting Policies and Options. Procedia Social and Behavioral Sciences, 62, 347-351. http://dx.doi.org/10.1016/j.sbspro.2012.09.055

Masood, O.; Tvaronavičienè, M.; Javaria, K. 2019. Impact of oil prices on stock return: evidence from G7 countries, Insights into Regional Development 1(2): 129-137. https://doi.org/10.9770/ird.2019.1.2(4)

MSCI(2018,April).ESGRatings Methodology:ExecutiveSummary. Retrieved fromhttps://www.msci.com/documents/10199/123a2b2b1395-4aa2-a121-ea14de6d708a

Nikitina, M.G.; Pobirchenko, V.V.; Shutaieva, E.A.; Karlova, A.I. 2018. The investment component in a nation's economic security: the case of the Russian Federation, Entrepreneurship and Sustainability Issues 6(2): 958-967. http://doi.org/10.9770/jesi.2018.6.2(32)

Ohotina, A.; Ignatjeva, S.; Lavrinenko, O., Lonska J. (2018). Socioeconomic security as a factor of the investment climate in the region, Journal of Security and Sustainability Issues 7(3): 427-438. https://doi.org/10.9770/jssi.2018.7.3(5)

Ozturk, A. (2016). Examining the economic growth and the middle-income trap from the perspective of the middle class, International Business Review 25: 726-738

Paseková, M.; Svitáková, B.; Kramná, E.; Otrusinová, M. (2017). Towards financial sustainability of companies: issues related to reporting errors, Journal of Security and Sustainability Issues 7(1): 141-153. https://doi.org/10.9770/jssi.2017.7.1(12)

Perry, B. (2017). Evaluating Country Risk for International Investing. Available on the Internet: http://www.investopedia.com/articles/ stocks/08/country-risk-for-international-investing.asp

Reischmann, M. (2016). Creative Accounting and Electoral Motives: Evidence from OECD Countries. Journal of Comparative Economics, 44(2): 243-257. http://dx.doi.org/10.1016/j.jce.2015.07.001

Shvetsova, O.A.; Rodionova, E.A.; Epstein, M. Z. 2018. Evaluation of investment projects under uncertainty: multi-criteria approach using interval data, Entrepreneurship and Sustainability Issues 5(4): 914-928. http://doi.org/10.9770/jesi.2018.5.4(15) 
Teletov, A.; Nagornyi, Y.; Letunovska, N.; Shevliuga, O. (2017). Competitive and sustainable technological development: focus on business enterprises, Journal of Security and Sustainability Issues 6(3): 491-500. http://dx.doi.org/10.9770/jssi.2017.6.3(13)

Tetiana, H.; Karpenko, L.; Fedoruk, O.; Shevchenko, I., \& Drobyazko, S. (2018). Innovative methods of performance evaluation of energy efficiency project. Academy of Strategic Management Journal, 17(2), 112-110. URL: https:/www.abacademies.org/articles/ innovative-methods-of-performance-evaluation-of-energy-efficiency-projects-7067.html

Tvaronavičienè, M. 2018. Toward efficient policy making: forecasts of vulnerability to external global threats, Journal of Security and Sustainability Issues 7(3): 591-600. https://doi.org/10.9770/jssi.2018.7.3(18)

Tvaronavičienè, M.; Černevičiūtè, J. (2015). Technology transfer phenomenon and its impact on sustainable development, Journal of Security and Sustainability Issues 5(1): 87-97. http://dx.doi.org/10.9770/jssi.2015.5.1(7)

Vorotnikov, I.L.; Sukhanova, I.F.; Lyavina, M.Y.; Glukhova, M.I.; Petrov, K.A. 2019. Economic sanctions and import substitution, Entrepreneurship and Sustainability Issues 6(4): 1872-1883. http://doi.org/10.9770/jesi.2019.6.4(23)

Mariia V. DYKHA, Doctor of Economics, Professor, Professor of the Department of Economics of Enterprise and Entrepreneurship, Khmelnytsky National University

ORCID ID: orcid.org/ 0000-0003-4405-9429

Larysa LIUBOKHYNETS, PhD in Economics, Associate Professor, Head of the Department of Economic theory, Khmelnytsky National University

ORCID ID: orcid.org/0000-0003-0958-130X

Nataliia P. TANASIIENKO, PhD in Economics, Associate Professor, Associate Professor of the Department of Economic theory, Khmelnytsky National University

ORCID ID: orcid.org/0000-0001-6887-903X

Serhiy MOROZ, PhD in Economics, Associate Professor, Associate Professor of the Department of Economic theory, Khmelnytsky National University

ORCID: ID: orcid.org/0000-0001-8136-3791

Olga POPLAVSKA, Senior lecturer of the Department of Economic theory, Khmelnytsky National University ORCID ID: orcid.org/0000-0003-0861-216X

Register for an ORCID ID:

https://orcid.org/register

This work is licensed under the Creative Commons Attribution International License (CC BY)

http://creativecommons.org/licenses/by/4.0/ 